\title{
SPOŁECZNA ODPOWIEDZIALNOŚĆ BIZNESU W STRATEGII ZARZĄDZANIA PRZEDSIĘBIORSTW PRZEMYSŁU PIWOWARSKIEGO W POLSCE
}

\author{
Małgorzata Idasiak \\ Politechnika Częstochowska \\ Wydział Zarządzania
}

\begin{abstract}
Streszczenie: Artykuł podejmuje tematykę etyki w kontekście zarządzania, ze szczególnym uwzględnieniem koncepcji społecznej odpowiedzialności biznesu (Corporate Social Responsibility). Publikacja powstała przy wykorzystaniu techniki desk research w drodze weryfikacji szerokiego studium krajowych i zagranicznych pozycji literaturowych przedmiotu oraz danych wtórnych podmiotów gospodarczych. Celem artykułu jest analiza porównawcza stopnia implementacji koncepcji CSR do strategii zarządzania kluczowych przedsiębiorstw przemysłu piwowarskiego w Polsce. Przeprowadzono klasyfikację podmiotów przemysłu piwowarskiego w Polsce pod względem udziału w rynku oraz stopnia implementacji koncepcji CSR do strategii zarządzania. W wyniku przeprowadzonej analizy wskazano na różnorodną dynamikę w procesie implementacji koncepcji CSR do strategii zarządzania kluczowych podmiotów branży piwowarskiej.
\end{abstract}

Słowa kluczowe: etyka, koncepcja społecznej odpowiedzialności biznesu, przemysł piwowarski, strategia, zarządzanie

DOI: $10.17512 /$ znpcz.2018.1.24

\section{Wprowadzenie}

Otoczenie współczesnych podmiotów gospodarczych charakteryzuje dynamika zmian, także w zakresie systemu wartości, relacji międzyludzkich czy kompetencji (Lewandowska 2010, s. 155-161). Zmiany zachodzące w zewnętrznym środowisku przedsiębiorstwa sygnalizują potrzebę przyjęcia dostosowanych narzędzi kierowania, uwzględniających aspekt tworzenia trwałych związków z kluczowymi interesariuszami, przyczyniających się do tworzenia wartości organizacji (Brzeziński 2016, s. 62). Wobec tego w XXI wieku w przestrzeni gospodarczej zaobserwowano wzrost zainteresowania aspektem etyki w kontekście zarządzania organizacją, co w konsekwencji doprowadziło do stworzenia koncepcji społecznej odpowiedzialności biznesu.

Bogaty zasób wiedzy literaturowej nie przekłada się jasno na faktyczną prezentację szeroko rozumianego kształtowania się myśli etycznej w kontekście zarządzania. Celem artykułu jest analiza porównawcza stopnia implementacji koncepcji CSR do strategii zarządzania kluczowych przedsiębiorstw przemysłu piwowarskiego w Polsce. W konsekwencji niniejszy artykuł stanowi prezentację zróżnicowanych definicji koncepcji społecznej odpowiedzialności biznesu oraz wskazuje 
spektrum zainteresowania koncepcją CSR kluczowych (pod względem udziału w rynku) podmiotów przemysłu piwowarskiego w Polsce.

Publikacja powstała w związku z wykorzystaniem analizy danych zastanych, w tym szerokiego studium krajowych i zagranicznych pozycji literatury.

W wyniku przeprowadzonych badań ukazano dynamikę oraz obszary implementacji koncepcji CSR do strategii zarządzania kluczowych podmiotów przemysłu piwowarskiego w Polsce.

\section{Etyka w strategii zarządzania}

Pojecie etyki związane jest z kształtowaniem i opisywaniem norm uznawanych w danym okresie czasu przez określoną zbiorowość społeczną jako punkt odniesienia dla oceny postępowania jednostki (Bokszańska 2011, s. 21). Etyka może stanowić czynnik wspierający integrację jednostek wokół pewnych akceptowanych wartości (Bugiel 2002, s. 84). W konsekwencji postępowanie etyczne postrzegane jest jako co najmniej niesprzeczne z przyjętymi w danym społeczeństwie i okresie normami moralnymi (Skalik 2010, s. 438).

Według J.A.F. Stonera etyka to nauka o tym, w jaki sposób zasady determinujące podejmowanie decyzji jednostki wpływają na innych ludzi i kształtujące się stosunki międzyludzkie (Stoner, Freeman, Gilbert 2011, s. 119). Natomiast R. Griffin pojęcie etyki interpretuje jako osobiste przekonanie jednostki dotyczące klasyfikacji zachowania pod względem jego poprawności w kontekście wyznawanych wartości (Griffin 2010, s. 135).

Na poziom etyki działalności gospodarczej wpływ ma wiele czynników (Tabela 1).

Tabela 1. Czynniki ksztaltujące poziom etyczny organizacji

Czynniki zewnetrzne

\begin{tabular}{|c|c|c|}
\hline System gospodarczy & \multirow{4}{*}{ Organizacja } & Moralność pracowników \\
\hline System prawny & & Polityka wewnętrzna \\
\hline System polityczny & & Misja \\
\hline Moralność spoleczeństwa & & Kultura organizacji \\
\hline
\end{tabular}

Źródło: Opracowanie własne na podstawie (Flaszewska, Lachiewicz, Nowicki 2013, s. 71)

Do głównych czynników zewnętrznych wpływających na etyczny kontekst zarządzania organizacją zalicza się system gospodarczy determinujący akceptowalny poziom etyki i propagowanych wartości w podmiotach gospodarczych (przykładem mogą być wartości propagowane w systemie kapitalistycznym, w kontekście systemu socjalistycznego). Do kluczowych czynników zewnętrznych mających wpływ na wymiar etyki w zarządzaniu zalicza się także system prawny (związany z przejrzystością norm oraz częstotliwością zmian w prawodawstwie, które oddziałują na obszar oraz konieczność wdrażania zmian w kontekście działalności gospodarczej), system polityczny (uwzględniający m.in. aktualny poziom demokracji i akceptowalny przez społeczeństwo czy wskaźnik dystansu władzy) oraz wykazywane przez społeczeństwo danego kraju normy i obyczaje. 
Do wewnętrznych determinantów etycznego zarządzania organizacją należy przede wszystkim sytuacja ekonomiczna organizacji (możliwość podejmowania etycznych decyzji, w tym odrzucania niemoralnych okazji biznesowych, kosztem utraty zysku), misja organizacji (zapisana w strategicznych dokumentach, mająca być przesłaniem skierowanym do wszystkich interesariuszy wewnętrznych, jak i zewnętrznych, odnośnie celu i kierunku działania przedsiębiorstwa), polityka organizacji (która może wspierać tworzenie odpowiedzialnej kultury organizacji, dzięki czemu pracownicy mogą przejmować aprobowane, przez kadrę zarządczą, wartości i normy) oraz poziom moralny pracowników - indywidualne postrzeganie etyki przez pracowników danej organizacji (Pabian, Pabian 2015, s. 65-72).

Interesariusze przedsiębiorstw mają istotny wpływ na kształt polityki zarządzania organizacją (w tym kwestie etyczne). Obok podmiotów bezpośrednio skorelowanych z działalnością gospodarczą przedsiębiorstwa coraz większe znaczenie w kształtowaniu odpowiedzialnego biznesu mają etyczni konsumenci, dla których czynnikiem determinującym decyzje zakupu dóbr i/lub usług (obok ceny czy jakości) może być odpowiedzialny kontekst zarządzania podmiotu gospodarczego (Dąbrowski 2010, s. 18).

\section{Koncepcja społecznej odpowiedzialności biznesu}

Społeczna odpowiedzialność biznesu (Corporate Social Responsibility - CSR) to koncepcja, w myśl której aspekt społeczeństwa, ochrony środowiska naturalnego oraz poszanowania postulatów szeroko rozumianych interesariuszy oddziałuje na kształt strategii zarządzania podmiotów gospodarczych (Daszkiewicz 2009, s. 205-222). Podejście to wskazuje, iż przedsiębiorcę powinna cechować odpowiedzialność za efekty działalności gospodarczej (Makuch 2011, s. 24).

Zdaniem P.F. Druckera „każda organizacja gospodarcza ponosi pełną odpowiedzialność za swój wpływ na społeczność lokalną i społeczeństwa, w których działa" (Hąbek 2009, s. 71).

W literaturze przedmiotu odnaleźć można różnorodne definicje koncepcji społecznej odpowiedzialności biznesu (Tabela 2).

Tabela 2. Definicje koncepcji społecznej odpowiedzialności biznesu

\begin{tabular}{|c|c|c|}
\hline Autor & Rok & Zaproponowana definicja \\
\hline J. McGuire & 1963 & $\begin{array}{c}\text { „Idea odpowiedzialności społecznej zakłada, } \\
\text { ze korporacja ma nie tylko obowiązi natury gospodarczej } \\
\text { i prawnej, ale również pewne zobowiazania wobec } \\
\text { społeczeństwa, które wykraczaja poza te obowiązki”. }\end{array}$ \\
\hline K. Davis & 1973 & $\begin{array}{c}\text { „Uwzględnianie oraz reagowanie przez firmę } \\
\text { na zagadnienia wykraczające poza wąskie gospodarcze, } \\
\text { techniczne i prawne wymagania wobec niej [...], } \\
\text { aby osiagnąć korzyści społeczne oprócz tradycyjnych zysków } \\
\text { ekonomicznych, do których dąży firma”. }\end{array}$ \\
\hline S.P. Sethi & 1975 & $\begin{array}{c}\text { „CSR polega na podniesieniu zachowań korporacyjnych do } \\
\text { poziomu, na którym odpowiadaja one dominujacym } \\
\text { spotecznym normom, wartościom i oczekiwaniom”. }\end{array}$ \\
\hline
\end{tabular}




\begin{tabular}{|c|c|c|}
\hline $\begin{array}{l}\text { K. Davis, } \\
\text { R. Blomstrom }\end{array}$ & 1975 & $\begin{array}{c}\text { „CSR to zobowiazania kadry zarzadczej } \\
\text { do podejmowania działań majacych na celu ochronę } \\
\text { i poprawe zarówno dobrobytu społeczeństwa, } \\
\text { jak i interesu organizacji”. }\end{array}$ \\
\hline A.B. Caroll & 1979 & $\begin{array}{c}\text { „Społeczna odpowiedzialność biznesu obejmuje ekonomiczne, } \\
\text { prawne, etyczne i uznaniowe oczekiwania, jakie społeczeństwo } \\
\text { ma wobec organizacji w danym czasie”. }\end{array}$ \\
\hline W.C. Frederick & 1978 & $\begin{array}{c}\text { „Społeczna reaktywność biznesu to zdolność korporacji do } \\
\text { reakcji na nacisk społeczny, dosłowny akt reakcji; } \\
\text { lub też do przyjęcia reaktywnej generalnie postawy wobec } \\
\text { społeczeństwa”. }\end{array}$ \\
\hline D.J. Wood & 1991 & $\begin{array}{c}\text { „Społeczna odpowiedzialność biznesu to przyjęta } \\
\text { w organizacji biznesowej konfiguracja zasad } \\
\text { odpowiedzialności społecznej, procesów reaktywności } \\
\text { społecznej oraz polityk, programów i widocznych wyników } \\
\text { powiąanych z relacjami społecznymi firmy”. }\end{array}$ \\
\hline $\begin{array}{l}\text { M. McIntosh, } \\
\text { A. Mohan }\end{array}$ & 1998 & $\begin{array}{c}\text { „Społecznie odpowiedzialny biznes dotyczy relacji między } \\
\text { spótkami i społeczeństwem - zarówno społecznościa lokalna, } \\
\text { która otacza biznes oraz której członkowie wchodza } \\
\text { w interakcje z pracownikami firmy, jak również szersza } \\
\text { społecznościa obejmujaca cały świat, która dotyka firm za } \\
\text { pośrednictwem ich produktów, łańcucha dostaw, sieci } \\
\text { dystrybutorów, reklam itd.". }\end{array}$ \\
\hline $\begin{array}{l}\text { I. Maignan, } \\
\text { O.C. Ferrell, } \\
\text { G.T.M. Hult }\end{array}$ & 1999 & $\begin{array}{c}\text { „Społecznie odpowiedzialny biznes oznacza to, w jakim } \\
\text { stopniu firma podejmuje ekonomiczne, prawne, etyczne } \\
\text { i uznaniowe zobowiązania naktadane na nia przez strony } \\
\text { zaangażowane w jej działalnośc”. }\end{array}$ \\
\hline $\begin{array}{c}\text { Komisja } \\
\text { Europejska }\end{array}$ & 2001 & $\begin{array}{c}\text { „Społeczna odpowiedzialność przedsiębiorstw rozumiana jako } \\
\text { koncepcja dobrowolnego uwzględniania przez firmę aspektów } \\
\text { społecznych i ekologicznych podczas prowadzenia dziatań } \\
\text { handlowych } i \text { wontaktach } \\
\text { z interesariuszami”. }\end{array}$ \\
\hline O. Bazzichi & 2003 & $\begin{array}{c}\text { „Społeczna odpowiedzialność przedsiębiorstw jest } \\
\text { dobrowolnym łaczeniem spraw społecznych } \\
\text { i gospodarczych w działalności handlowej } i \text { w stosunkach } \\
\text { z interesariuszami, którymi sa pracownicy, klienci, dostawcy, } \\
\text { społeczność, w której firma działa, oraz rząd } \\
\text { i media”. }\end{array}$ \\
\hline $\begin{array}{l}\text { Światowa } \\
\text { Rada Biznesu } \\
\quad \text { ds. } \\
\text { Zrównoważoneg } \\
\text { o Rozwoju }\end{array}$ & 2004 & $\begin{array}{c}\text { „CSR to ciagłe zobowiazanie biznesu do zachowań etycznych } \\
\text { oraz do działań na rzecz rozwoju ekonomicznego, przy } \\
\text { jednoczesnej trosce o poprawé jakości życia pracowników } \\
\text { i ich rodzin, społeczności lokalnej oraz całego } \\
\text { społeczeństwa”. }\end{array}$ \\
\hline ISO 26000 & 2008 & $\begin{array}{c}\text { „Społeczna odpowiedzialność rozumiana jest } \\
\text { jako odpowiedzialność organizacji za skutki podejmowanych } \\
\text { decyzji i działań wobec spoleczeństwa } \\
\text { i środowiska. Odpowiedzialność ta realizowana jest przez } \\
\text { przejrzyste i etyczne zachowania, które: } \\
\text {-przyczyniaja się do zrównoważonego rozwoju, zdrowia }\end{array}$ \\
\hline
\end{tabular}




\begin{tabular}{|c|c|c|}
\hline & & $\begin{array}{c}\text { i dobrobytu spolecznego; } \\
\text {-uwzględniaja oczekiwania interesariuszy; } \\
\text {-sq zgodne z obowiazujacym prawem } \\
\text { i międzynarodowymi normami zachowań; } \\
\text { - sq zintegrowane w calej organizacji i praktykowane } \\
\text { w jej relacjach". }\end{array}$ \\
\hline $\begin{array}{l}\text { A. Paliwoda- } \\
\text {-Matiolańska }\end{array}$ & 2009 & $\begin{array}{l}\text { „Społeczna odpowiedzialność przedsiębiorstw } \\
\text { to efektywny proces zarzadzania przedsiębiorstwem, } \\
\text { który przez odpowiadanie na możliwe do zidentyfikowania } \\
\text { oczekiwania interesariuszy przedsiębiorstwa przyczynia się do } \\
\text { wzrostu jego konkurencyjności, zapewniając mu stabilność } \\
\text { i trwały rozwój, jednocześnie kształtuje korzystne warunki do } \\
\text { rozwoju ekonomicznego i spotecznego, tworzac wartość } \\
\text { zarówno społeczną, jak i ekonomiczną”. }\end{array}$ \\
\hline P. Roszkowska & 2011 & $\begin{array}{c}\text { „Spoteczna odpowiedzialność przedsiębiorstwa } \\
\text { to dobrowolne uwzględnianie interesów społecznych oraz } \\
\text { dialogu z interesariuszami w strategii oraz działaniach } \\
\text { operacyjnych przedsiębiorstwa, co pozwala podejmować } \\
\text { decyzje korzystne dla jednostki gospodarczej } \\
\text { i jej otoczenia”. }\end{array}$ \\
\hline
\end{tabular}

Źródło: Opracowanie własne na podstawie (Stecko 2012, s. 120; Paliwoda-Matiolańska 2009, s. 272; Piłacik 2017, s. 86; ISO-PKN 2010; Bazzichi 2003, s. 496; GAEA b.r.; Davis 1973, s. 312; Sethi 1975, s. 59; Carroll 1979, s. 498; Frederick 1978, s. 152; Swaen 2012; Roszkowska 2011, s. 39)

Zaprezentowane definicje CSR łączy fakt silnej więzi pomiędzy organizacją a otoczeniem. Stąd postulowanie o odpowiedzialne podjęcie współpracy w zakresie dbania zarówno o interesy ekonomiczne, jak i społeczne, w poszanowaniu szeroko rozumianych interesariuszy.Kadra zarządcza w trakcie implementacji do strategii zarządzania koncepcji społecznej odpowiedzialności powinna uwzględnić kluczowe obszary koncepcji CSR (Tabela 3).

Tabela 3. Główne obszary koncepcji społecznej odpowiedzialności biznesu

\begin{tabular}{|c|c|c|c|c|}
\hline & Środowisko & Interesariusze & Produkt & Pracownicy \\
\hline 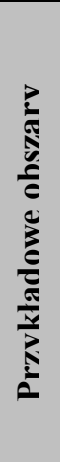 & $\begin{array}{c}\text { emisja gazów } \\
\text { cieplarnianych } \\
\text { ilość odpadów } \\
\text { wytworzonych w trakcie } \\
\text { produkcji } \\
\text { wykorzystywanie } \\
\text { zasobów naturalnych } \\
\text { wykorzystywanie } \\
\text { odnawialnych źródeł } \\
\text { energii }\end{array}$ & $\begin{array}{c}\text { współtworzenie } \\
\text { lokalnej } \\
\text { społeczności }\end{array}$ & $\begin{array}{c}\text { znakowanie } \\
\text { produktów } \\
\text { jakość } \\
\text { produktów } \\
\text { bezpieczeńst } \\
\text { wo produktów }\end{array}$ & $\begin{array}{c}\text { odpowiedzialne } \\
\text { zasady } \\
\text { zatrudnienia } \\
\text { BHP } \\
\text { szkolenia } \\
\text { i rozwój etyki za- } \\
\text { wodowej } \\
\text { etyczne infolinie } \\
\text { wpierające } \\
\text { sygnalistów }\end{array}$ \\
\hline
\end{tabular}

Źródło: Opracowanie własne na podstawie (Nalepka, Ujwar-Gil 2010, s. 183; GRI 2016) 
W obszar zainteresowania koncepcji społecznej odpowiedzialności biznesu wpisuje się aspekt poszanowania środowiska (w szczególności skończoności zasobów surowców naturalnych, a także ograniczania negatywnych skutków działalności gospodarczej), zapewnienia odpowiednich warunków pracy interesariuszom wewnętrznym, edukacji pracowników (zarówno pod względem ścieżki zawodowej, jak i odnośnie ekologii i ekologicznych procesów wytwórczych) oraz odpowiedzialnej produkcji dóbr i/lub usług (Nalepka, Ujwar-Gil 2010, s. 183).

Podmiot gospodarczy funkcjonujący na rynku zgodnie z przyjętymi zasadami koncepcji CSR może również motywować partnerów biznesowych do etycznego kontekstu zarządzania, a także wpływać na odpowiedzialne wybory konsumentów, za sprawą wykorzystywania znaków umieszczanych na produktach, określających m.in. stopień ekologiczności wyrobu (Wielgórka 2016, s. 983; Otola, Nitkiewicz 2013, s. 518-520).

Angażowanie się organizacji w koncepcję CSR wiąże się z potrzebą posiadania odpowiedniego know-how oraz koniecznością poniesienia dodatkowych kosztów (Zachorowska, Płonka 2007, s. 492).

\section{Polski przemysł piwowarski w aspekcie społecznej odpowiedzialności biznesu}

Zgodnie z tablicami REGON, przy uwzględnieniu PKD (stan na 31.03.2018), w Polsce działają 324 podmioty sektora sekcji C (Przetwórstwo przemysłowe), działu 11.05Z (Produkcja napojów - produkcja piwa). Według danych Państwowej Agencji Rozwiązywania Problemów Alkoholowych od kilku lat w Polsce spożycie piwa per capita utrzymuje się na stabilnym poziomie, oscylując w granicach 96-98 litrów (PARPA 2016).

Tendencja wzrostu sektora widoczna jest także w Europie. Zgodnie z raportem The Brewers of Europe (2017) największym producentem przemysłu piwowarskiego na terenie Europy są Niemcy $(94957 \mathrm{hl})$, następnie Wielka Brytania (43 734 hl) oraz Polska (41 369 hl). Szacuje się, iż w całej Europie aktualnie funkcjonuje 8490 browarów, które łącznie w ciągu ostatniego roku wyprodukowały $400168000 \mathrm{hl}$ piwa, zatrudniając blisko 2300000 pracowników, (The Brewers of Europe 2017, s. 6-10).

Tabela 4. Kluczowe podmioty przemysłu piwowarskiego w Polsce

\begin{tabular}{cccc}
\hline & Kompania Piwowarska SA & Grupa Żywiec SA & Carlsberg Polska SA \\
\hline \multirow{2}{\text{Zrzeszane}}{$\begin{array}{c}\text { Browar Bracki } \\
\text { browary }\end{array}$} & $\begin{array}{c}\text { Browar Dojlidy } \\
\text { Browar Książęcy } \\
\text { Browar Lech }\end{array}$ & $\begin{array}{c}\text { Browar Elbląg } \\
\text { Browar Leżajsk } \\
\text { Browar Warka } \\
\text { Browar Żywiec }\end{array}$ & $\begin{array}{c}\text { Browar Bosman } \\
\text { Browar Kasztelan } \\
\text { Browar Okocim }\end{array}$ \\
$\begin{array}{c}\text { Udzial } \\
\text { w rynku }\end{array}$ & $36,9 \%$ & $34 \%$ & $20 \%$ \\
\hline
\end{tabular}

Źródło: Opracowanie własne na podstawie (Kompania Piwowarska 2017; Carlsberg 2017; Grupa Żywiec 2016) 
Przemysł piwowarski w Polsce, mimo znacznych rozmiarów (pod względem ilości podmiotów) czy uznanej pozycji w Europie, jest zdominowany przez trzy największe (pod względem udziału w rynku) podmioty (Tabela 4).

$\mathrm{Na}$ przestrzeni ostatnich lat zaangażowanie w tworzenie raportów niefinansowych w polskim przemyśle piwowarskim znacznie wzrosło (Tabela 5). Pionierem w zakresie raportowania danych niefinansowych w branży jest Kompania Piwowarska SA, która po raz dziewiąty publikuje raport odnośnie danych niefinansowych. Stopień implementacji postulatów koncepcji CSR do strategii zarządzania Kompanii Piwowarskiej SA został doceniony w postaci przyznania przez tygodnik „Polityka” Złotego Listka CSR („Polityka” 2017) oraz przez zajęcie miejsca w diamentowej dziewiątce (92 pkt) XI Rankingu Odpowiedzialnych Firm 2017 (szerzej: Ranking Odpowiedzialnych Firm 2017).

Tabela 5. Wykaz kluczowych podmiotów branży piwowarskiej sporządzających raporty CSR według wytycznych GRI na przestrzeni lat 2012-2017

\begin{tabular}{|c|c|c|c|c|c|c|}
\hline & 2017 & 2016 & 2015 & 2014 & 2013 & 2012 \\
\hline $\begin{array}{c}\text { Kompania } \\
\text { Piwowarska } \\
\text { SA }\end{array}$ & $\begin{array}{c}\text { GRI - G4 } \\
\text { wersja } \\
\text { podstawowa }\end{array}$ & $\begin{array}{c}\text { GRI - G4 } \\
\text { wersja } \\
\text { podstawowa }\end{array}$ & $\begin{array}{c}\text { GRI - G4 } \\
\text { wersja } \\
\text { podstawowa }\end{array}$ & $\begin{array}{c}\text { GRI - G4 } \\
\text { wersja } \\
\text { podstawowa }\end{array}$ & $\begin{array}{c}\text { GRI - G4 } \\
\text { wersja } \\
\text { podstawowa }\end{array}$ & $\begin{array}{l}\text { GRI - G3.1 } \\
\text { poziom B+ }\end{array}$ \\
\hline $\begin{array}{c}\text { Grupa } \\
\text { Żywiec SA }\end{array}$ & & $\begin{array}{c}\text { GRI - G4 } \\
\text { wersja } \\
\text { podstawowa }\end{array}$ & & $\begin{array}{c}\text { GRI - G4 } \\
\text { wersja } \\
\text { podstawowa }\end{array}$ & $\begin{array}{c}\text { GRI - G4 } \\
\text { wersja } \\
\text { podstawowa }\end{array}$ & $\begin{array}{l}\text { GRI - G3.1 } \\
\text { poziom B+ }\end{array}$ \\
\hline $\begin{array}{l}\text { Carlsberg } \\
\text { Polska SA }\end{array}$ & $\begin{array}{c}\text { GRI - G4 } \\
\text { wersja } \\
\text { podstawowa }\end{array}$ & $\begin{array}{c}\text { GRI - G4 } \\
\text { wersja } \\
\text { podstawowa }\end{array}$ & & & & \\
\hline
\end{tabular}

Źródło: Opracowanie własne na podstawie raportów CSR

Zgodnie z zestawieniem (Tabela 5) kluczowe spółki branży piwowarskiej $\mathrm{w}$ Polsce raportują dane niefinansowe w podstawowej wersji (core), od lat zgodnie z międzynarodowymi wytycznymi GRI (Global Reporting Initiative). Na przestrzeni lat 2012-2017 jedynie lider rynku - Kompania Piwowarska sporządzała raporty społeczne regularnie, ukazując informacje w porównywalnych okresach. Kadra zarządcza Grupy Żywiec SA w badanym okresie sporządziła raport społeczny czterokrotnie, natomiast Carlsberg Polska SA raportowanie danych niefinansowych stosuje jedynie zgodnie z obowiązującymi uwarunkowaniami prawnymi.

Raporty społeczne kluczowych podmiotów polskiego przemysłu piwowarskiego obejmują zbliżone obszary (Tabela 6 ). 
Tabela 6. Wykaz obszarów implementacji koncepcji społecznej odpowiedzialności biznesu do strategii zarządzania kluczowych podmiotów przemysłu piwowarskiego w Polsce

\begin{tabular}{|c|c|c|c|}
\hline & Kompania Piwowarska SA & Grupa Żywiec SA & Carlsberg Polska SA \\
\hline 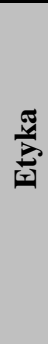 & $\begin{array}{l}\text { Kodeks Etyki } \\
\text { Platforma on-line Whistle- } \\
\text { blowing Policy } \\
\text { Coroczne sprawozdanie } \\
\text { z działalności Komisji Etyki } \\
\text { dostępne dla pracowników } \\
\text { Polityka Antykorupcyjna - } \\
\text { Fraud Risk Assessment } \\
\text { Questionnaire }\end{array}$ & $\begin{array}{l}\text { Kodeks Postępowania } \\
\text { w Biznesie HEINEKEN }\end{array}$ & $\begin{array}{l}\text { Kodeks Etyki Reklamy } \\
\text { Kodeks Etyki i Postępowania dla } \\
\text { Pracowników } \\
\text { Anonimowa Infolinia SpeakUp }\end{array}$ \\
\hline 苋 & $\begin{array}{l}\text { E-mail } \\
\text { Infolinia } \\
\text { Media społecznościowe }\end{array}$ & $\begin{array}{l}\text { Infolinia } \\
\text { Media społecznościowe } \\
\text { Magazyn firmowy } \\
\text { „Biromaniak” } \\
\text { Badanie satysfakcji }\end{array}$ & $\begin{array}{l}\text { E-mail } \\
\text { Infolinia } \\
\text { Media społecznościowe }\end{array}$ \\
\hline \multirow{5}{*}{ 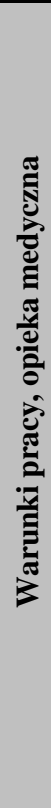 } & $\begin{array}{l}21 \text { wypadków skutkujących } \\
\text { zwolnieniem lekarskim } \\
0 \text { wypadków ciężkich } \\
\text { i śmiertelnych }\end{array}$ & $\begin{array}{l}25 \text { wypadków skutkujących } \\
\text { zwolnieniem lekarskim }\end{array}$ & $\begin{array}{l}4 \text { wypadki skutkujące zwolnieniem } \\
\text { lekarskim }\end{array}$ \\
\hline & $\begin{array}{l}\text { Firmowe puby } \\
\text { w Warszawie, Tychach, } \\
\text { Poznaniu i Białymstoku, } \\
\text { w ramach akcji „KP po } \\
\text { godzinach” }\end{array}$ & $\begin{array}{l}\text { Szkolenia w ramach } \\
\text { Tygodnia Bezpieczeństwa } \\
\text { (ang. SHE Week) }\end{array}$ & $\begin{array}{l}\text { Browar Okocim - nagroda Best in } \\
\text { Class BHP }\end{array}$ \\
\hline & $\begin{array}{l}\text { Preferencyjne oferty } \\
\text { sprzedaży samochodów, } \\
\text { produktów bankowych oraz } \\
\text { darmowe vouchery na } \\
\text { wydarzenia społeczno- } \\
\text { kulturalne }\end{array}$ & $\begin{array}{l}\text { Badanie klimatu pracy - } \\
\text { ankieta }-1416 \\
\text { respondentów }\end{array}$ & $\begin{array}{l}\text { Standaryzacja środków ochrony } \\
\text { indywidualnej }\end{array}$ \\
\hline & $\begin{array}{l}\text { Personalizowana ścieżka } \\
\text { kariery }\end{array}$ & $\begin{array}{l}\text { Program Rozwoju Talentów } \\
\text { - TalentsLabs 5.0, z którego } \\
\text { skorzystało } 95 \text { pracowników }\end{array}$ & \multirow[t]{2}{*}{$\begin{array}{l}\text { Kampania informacyjna } \\
\text {,Traffic Safety”, }\end{array}$} \\
\hline & $\begin{array}{l}8000 \text { dni szkoleniowych w } \\
2017 \text { roku rozliczeniowym }\end{array}$ & $\begin{array}{l}1243 \text { dni szkoleniowe } \\
\text { w } 2017 \text { roku } \\
\text { rozliczeniowym }\end{array}$ & \\
\hline \multirow{2}{*}{$\frac{2}{\frac{d}{2}}$} & $\begin{array}{l}\text { Kwota } 1 \text { mln złotych } \\
\text { przekazana na akcje } \\
\text { LECHSTARTER }\end{array}$ & $\begin{array}{l}64550 \text { zł przekazane } \\
\text { z Funduszu Społecznego na } \\
\text { rzecz lokalnych projektów } \\
\text { Męskie Granie }\end{array}$ & $\begin{array}{l}\text { Globalne Dni Odpowiedzialnej } \\
\text { Konsumpcji Piwa - } 25 \mathrm{mln} \\
\text { odbiorców }\end{array}$ \\
\hline & $\begin{array}{l}30000 \text { zł przeznaczone na } \\
\text { akcję „Postaw na ruch”, }\end{array}$ & $\begin{array}{l}\text { Muzeum browaru w Żywcu } \\
\text { wpisany do Europejskiego } \\
\text { Dziedzictwa } \\
\text { Przemysłowego }\end{array}$ & $\begin{array}{l}\text { Platforma } \\
\text { Odpowiedzialnysprzedawca.pl }\end{array}$ \\
\hline
\end{tabular}




\begin{tabular}{|c|c|c|c|}
\hline & $\begin{array}{l}\text { Szlachetna Kompania } \\
\text { Wolontariuszy }\end{array}$ & $\begin{array}{l}\text { Konkurs Piw } \\
\text { Pracowniczych i Giełda } \\
\text { Birofilów w Żywcu } \\
\end{array}$ & $\begin{array}{l}\text { Program grantowy InicJaTyWy - } \\
213000 \mathrm{zł}\end{array}$ \\
\hline & $\begin{array}{l}\text { Trzeźwobusy na Imprezach } \\
\text { masowych }\end{array}$ & $\begin{array}{l}\text { Fundacja Rozwoju } \\
\text { Przyszłości - stypendia dla } \\
\text { dzieci pracowników o } \\
\text { łącznej wartości } 1,54 \text { mln zł }\end{array}$ & \multirow[t]{2}{*}{$\begin{array}{l}\text { Znaczniki odpowiedzialnego } \\
\text { spożycia }\end{array}$} \\
\hline & $\begin{array}{l}\text { Znaczniki odpowiedzialnego } \\
\text { spożycia }\end{array}$ & $\begin{array}{l}\text { Kampania „Trzymaj pion”i } \\
\text { znaczniki odpowiedzialnego } \\
\text { spożycia }\end{array}$ & \\
\hline \multirow{4}{*}{ 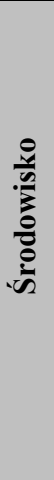 } & $\begin{array}{l}\text { Emisje } \mathrm{CO}_{2} \text { na poziomie } 2,8 \\
\mathrm{~kg} / \mathrm{hl}\end{array}$ & $\begin{array}{l}\text { Emisje } \mathrm{CO}_{2} \text { na poziomie } 6,4 \\
\mathrm{~kg} / \mathrm{hl}\end{array}$ & $\begin{array}{l}\text { Emisje } \mathrm{CO}_{2} \text { na poziomie } \\
3,13 \mathrm{~kg} / \mathrm{hl}\end{array}$ \\
\hline & 2,68 hl wody/hl piwa & $3,5 \mathrm{hl}$ wody/hl piwa & $3,2 \mathrm{hl}$ wody/hl piwa \\
\hline & $\begin{array}{l}\text { Kampania „Bądź madry, } \\
\text { bądź eko” }\end{array}$ & $\begin{array}{l}99 \% \text { energii elektrycznej } \\
\text { potrzebnej do produkcji } \\
\text { pochodzi ze źródeł } \\
\text { odnawialnych } \\
53,8 \% \text { piw sprzedanych } \\
\text { w opakowaniach zwrotnych }\end{array}$ & $\begin{array}{l}\text { Kampania „Naturze się należy” } \\
\text { Butelka Fiber Bootle } \\
\text { Certyfikat Zielone Biuro }\end{array}$ \\
\hline & $\begin{array}{l}95,45 \% \text { odpadów } \\
\text { poddawanych procesowi } \\
\text { odzysku }\end{array}$ & $\begin{array}{l}\text { Co najmniej } 50 \% \text { odpadów } \\
\text { poddawanych procesowi } \\
\text { odzysku }\end{array}$ & $\begin{array}{l}17 \% \text { energii elektrycznej } \\
\text { potrzebnej do produkcji pochodzi } \\
\text { ze źródeł odnawialnych }\end{array}$ \\
\hline
\end{tabular}

Źródło: Opracowanie własne na podstawie (Kompania Piwowarska 2017; Carlsberg 2017;

Grupa Żywiec 2016)

Stopień implementacji koncepcji społecznej odpowiedzialności biznesu do strategii zarządzania kluczowych podmiotów przemysłu piwowarskiego koncentruje się głównie w obszarze środowiska naturalnego, społeczeństwa oraz wewnętrznych interesariuszy. Omawiane podmioty w podobny sposób odniosły się w strategii zarządzania do kwestii tworzenia kodeksów etyki oraz kanałów do anonimowego sygnalizowania nieprawidłowości. Podobieństwo działań w zakresie etycznego zarządzania odnaleźć można także $\mathrm{w}$ obszarze komunikacji $\mathrm{z}$ interesariuszami oraz zapewnienia odpowiednich warunków pracy czy mierzenia oddziaływania na środowisko naturalne.

W prezentowanych raportach społecznych zasadniczą część stanowią wskaźniki dotyczące działań związanych z lokalną społecznością. Wszystkie omawiane grupy piwowarskie solidarnie uczestniczą $\mathrm{w}$ odpowiedzialnym znakowaniu swoich produktów, a także kampaniach przeciwdziałaniu nadmiernemu spożywaniu alkoholu. Zgodnie $\mathrm{z}$ przedstawionymi $\mathrm{w}$ raportach społecznych danymi kluczowe podmioty przemysłu piwowarskiego uczestniczyły w licznych działaniach charytatywnych.

\section{Podsumowanie}

Zmieniające się otoczenie oraz rosnąca świadomość zarówno społeczeństwa, jak i inwestorów podmiotów gospodarczych (także w kontekście etyki w dziedzinie zarządzania) spowodowały zmiany w sposobie kreowania strategii przedsiębiorstwa (Herbuś 2015, s. 26-27). Wobec postulowanej moralności w przestrzeni gospodar- 
czej oraz odpowiedzialnego wykorzystywania zasobów naturalnych etyczne koncepcje stają się parametrem wpływającym na wartość organizacji (Seroka-Stolka 2013, s. 12-18). Kadra zarządcza w trakcie tworzenia strategii przedsiębiorstwa powinna zdecydować o zakresie odpowiedzialności. Zakres ten może obejmować przystosowanie działań biznesowych do wymagań ustawodawstwa i redukowania efektów ubocznych działalności gospodarczej, poszanowania potrzeb interesariuszy lub współtworzenia wartości dla organizacji i społeczeństwa.

Na podstawie rankingów podmiotów społecznie odpowiedzialnych publikowanych przez tygodnik „Polityka” oraz rankingu Odpowiedzialnych Firm, można powiedzieć, że koncepcja CSR przenika niemal wszystkie sektory polskiej gospodarki. Na szczególną uwagę zasługuje przemysł piwowarski, który w ramach swej cały czas rozwijającej się (wzrost spożycia piwa, wzrost liczby browarów na terytorium Polski) działalności silnie koreluje z innymi branżami, wspierając polską gospodarkę.

Zgodnie z przeprowadzoną analizą stopień implementacji postulatów koncepcji CSR na przestrzeni lat 2012-2017 w kluczowych podmiotach przemysłu piwowarskiego w Polsce zwiększył się. Konieczność wdrażania kwestii etyki do strategii zarządzania przedsiębiorstwem oraz regularnego publikowania danych niefinansowych była respektowana przez dwa najsilniej oddziałujące na rynku (pod względem udziału w rynku) podmioty.

Wykazany sposób interpretacji postulatów CSR w strategii zarządzania kluczowych podmiotów przemysłu piwowarskiego w Polsce może wskazywać na potrzebę tworzenia etycznych modeli zarządzania uwzględniających specyfikę branży

\section{Literatura}

1. Bazzichi O. (2003), Społeczna odpowiedzialność przedsiębiorstwa, „Społeczeństwo. Studia, prace badawcze, dokumenty z zakresu nauki społecznej Kościoła”, nr 55/56(3/4).

2. Bokszańska G. (2011), Etyka - biznes - zarządzanie, Monografie Politechniki Łódzkiej, Łódź.

3. Brzeziński S. (2016), Zarządzanie przedsiębiorstwem społecznie odpowiedzialnym a globalne procesy integracji. Wybrane zagadnienia, PWE, Warszawa.

4. Bugiel J. (2002), Zarzadzanie. Aspekty psychologiczne $i$ socjologiczne, Uczelniane Wydawnictwa Naukowo-Dydaktyczne AGH, Kraków.

5. Carlsberg (2017), Sustainability Report 2017, https://carlsbergpolska.pl/media/22525/ carlsberg-group-sustainability-report-2017.pdf (dostęp: 15.04.2017).

6. Carroll A.B. (1979), A Three-Dimensional Conceptual Model of Corporate Performance, „Academy of Management Review”, Vol. 4(4), s. 497-505. DOI: 10.2307/257850

7. Daszkiewicz M. (2009), Budowanie relacji z otoczeniem - biznes wobec spolecznej odpowiedzialności, [w:] Przybyła M. (red.), Wybrane aspekty zarzadzania, Wydawnictwo Indygo Zahir Media, Wrocław, s. 1-18.

8. Davis K. (1973), The Case for and Against Business Assumption of Social Responsibilities, „Academy of Management Journal”, Vol. 16, s. 312-322. DOI: 10.2307/255331

9. Dąbrowski T. (2010), Reputacja przedsiębiorstwa, Wolters Kluwer, Kraków.

10. Flaszewska S., Lachiewicz S., Nowicki M. (red.) (2013), Społeczne i organizacyjne czynniki rozwoju przedsiębiorczości, Wydawnictwo Politechniki Łódzkiej, Łódź. 
11. Frederick W.C. (1978), From CSR1 to CSR2 - The Maturing of the Business and Society Thought, „Business and Society”, Vol. 33(2), s. 150-164. DOI: 10.1177/0007650394033 00202

12. GAEA (b.r.), World Business Council for Sustainable Development (WBCSD), http://www.gaea.bg/about-GAEA/corporate-social-responsibility.html (dostęp: 15.04.2017).

13. GRI (2016), G4. Wytyczne dotyczace raportowania. Podręcznik stosowania wytycznych, Amsterdam, http://pihrb.org/wp-content/uploads/2016/06/Polish-G4-Part-Two-Final.pdf (dostęp: 15.04.2017).

14. Griffin R.W. (2010), Podstawy zarządzania organizacjami, Wydawnictwo Naukowe PWN, Warszawa.

15. Grupa Żywiec (2016), Impact Report Żywiec 2016, http://www.grupazywiec.pl/wp-content/ uploads/2017/08/Warzymy-Lepszy-\%c5\%9awiat-Raport-wp\%c5\%82ywu-Grupy-Kapita\% c5\%82owej-\%c5\%bbywiec-za-2016-rok-16-sierpnia.compressed.pdf (dostęp: 15.04.2017).

16. Hąbek P. (2009), Spoleczna odpowiedzialność przedsiębiorstw jako koncepcja firmy zorientowanej na interesariuszy, „Organizacja i Zarządzanie”, nr 02, s. 69-86.

17. Herbuś I. (2015), Społeczna odpowiedzialność biznesu jako efekt zmian zachodzacych w przedsiębiorstwach, [w:] Wielgórka D. (red.), Zarządzanie współczesnymi organizacjami - uwarunkowania strategiczne, finansowe, innowacyjne, społeczne, Wydawnictwo Wydziału Zarządzania Politechniki Częstochowskiej, Częstochowa, s. 26-33.

18. ISO-PKN (2010), ISO 26000. Spoleczna Odpowiedzialność, https://www.pkn.pl/sites/ default/files/sites/default/files/imce/files/discovering_iso_26000.pdf (dostęp: 15.04.2017).

19. Kompania Piwowarska (2017), Sustainability Report FY17, http://www.kp.pl/files/social reports/pol/Raport_SD_2017.pdf(dostęp: 15.04.2017).

20. Lewandowska M. (2010), Tendencje zmian $w$ makrootoczeniu - perspektywa polskich przedsiębiorstw, „Zeszyty Naukowe Kolegium Gospodarki Światowej SGH”, nr 27, s. $155-179$.

21. Nalepka A., Ujwar-Gil A. (red.) (2010), Organizacje komercyjne i niekomercyjne wobec wzmożonej konkurencji oraz wzrastajacych wymagań konsumentów, Wyższa Szkoła Biznesu - National-Louis University, Nowy Sącz.

22. Otola I., Nitkiewicz T. (2013), Wykorzystanie zasobów relacyjnych przez przedsiębiorstwa produkcyjne z sektora MŚP przy podejmowaniu przedsięwzięć proekologicznych, [w:] Brzóska J., Pyka J. (red.), Nowoczesność przemystu i usług $w$ warunkach kryzysu i nowych wyzwań, TNOiK O. Katowice, Katowice, s. 518-530.

23. Pabian A., Pabian B. (2015), Kultura organizacyjna przedsiębiorstwa oparta na wartościach sustainability, „Ekonomika i Organizacja Przedsiębiorstwa”, nr 4, s. 65-72.

24. Paliwoda-Matiolańska A. (2009), Odpowiedzialność społeczna $w$ procesie zarządzania przedsiębiorstwem, C.H. Beck, Warszawa.

25. PARPA (2016), Statystyka, Państwowa Agencja Rozwiązywania Problemów Alkoholowych, http://www.parpa.pl/index.php/badania-i-informacje-statystyczne/statystyki (dostęp: 15.04.2017)

26. Piłacik J. (2017), Raportowanie wskaźników środowiskowych wedtug wytycznych Global Reporting Initiative na przykładzie polskich spótek branży energetycznej, „Prace Naukowe Uniwersytetu Ekonomicznego we Wrocławiu”, nr 470, s. 85-96. DOI: 10.15611/pn.2017. 470.08

27. „Polityka” (2017), Ranking Listki CSR Polityki, https://www.polityka.pl/tygodnikpolityka/ rynek/1702696,1,przyznalismy-zlote-srebrne-i-biale-listki-csr-polityki-2017.read (dostęp: 15.04.2017).

28. Ranking Odpowiedzialnych Firm 2017, http://rankingodpowiedzialnychfirm.pl/2017/05/xiranking-odpowiedzialnych-firm-wyniki/ (dostęp: 15.08.2017).

29. Roszkowska P. (2011), Rewolucja w raportowaniu biznesowym. Interesariusze, konkurencyjność, społeczna odpowiedzialność, Difin, Warszawa. 
30. Seroka-Stolka O. (2013), Ekologiczna i społeczna odpowiedzialność w budowaniu wartości przedsiębiorstwa, [w:] Ziółkowska B. (red.), Wybrane problemy z teorii i praktyki zarządzania wartościa w przedsiębiorstwie, Sekcja Wydawnictw Wydziału Zarządzania Politechniki Częstochowskiej, Częstochowa, s. 11-20.

31. Sethi S. P. (1975), Dimensions of Corporate Social Performance: An analytical Framework, „California Management Review”, Vol. 17(3), s. 58-64. DOI: 10.2307/ 41162149

32. Skalik J. (red.) (2010), Zmiana warunkiem sukcesu. Odnowa przedsiębiorstw - czego nauczyt nas kryzys?, Wydawnictwo Uniwersytetu Ekonomicznego we Wrocławiu, Wrocław.

33. Stecko J. (2012), CSR 1.0 a CSR 2.0 porównanie $i$ analiza pojęć, „Zeszyty Naukowe Politechniki Rzeszowskiej. Zarządzanie i Marketing”, nr 19(3), s. 119-125. DOI: 10.7862/rz.2012.zim.10

34. Stoner J.A.F., Freeman R.E., Gilbert D.R. Jr. (2011), Kierowanie, PWE, Warszawa.

35. Swaen V. (2012), Corporate Social Responsibility: Do Managers and Consumers Have the Same Conception of „Doing Good”?, 10th International Conference of the Greening of Industry Network June 23-26, Göteborg, Sweden.

36. The Brewers of Europe (2017), Beer Statistic. 2017 Edition, December, Brussels, https://www.brewersofeurope.org/uploads/mycmsfiles/documents/publications/2017/Statistics-201712-001.pdf (dostęp: 15.04.2017).

37. Wielgórka D. (2016), Environmental Management in the Aspect of Sustainable Development in Micro-, Small-, and Medium-Sized Enterprises, „Desalination and Water Treatment", Vol. 57, s. 982-992. DOI: 10.1080/19443994.2015.1017322

38. Zachorowska A., Płonka M. (2007), Effect of the European Union Environmental Requirements on Investment Strategies of Polish Enterprises, microCAD. International Scientific Conference. Section O: Economic Challenges II, Miskolc, s. 491-495.

\title{
CORPORATE SOCIAL RESPONSIBILITY IN THE MANAGEMENT STRATEGY OF BREWING INDUSTRY ENTERPRISES IN POLAND
}

\begin{abstract}
The focus of the present study is the topic of ethics in the context of management, with particular emphasis on the concept of Corporate Social Responsibility. The publication was created using the desk research technique by verifying a broad study of national and foreign publications on this subject and secondary data of business entities. The aim of the article is to present a comparative analysis of the degree of implementation of the CSR concept in management strategy of key enterprises of the brewing industry in Poland. The article classifies brewing industry entities in Poland according to their market share and the degree of implementation of the CSR concept in their management strategy. The results of the analysis point out to the diverse dynamics in the process of implementing the CSR concept in management strategy of key players in the brewing industry.
\end{abstract}

Keywords: ethics, the concept of Corporate Social Responsibility, brewing industry, strategy, management 